\title{
Acceleration of blue cheese ripening by cheese slurry and extracellular enzymes of Penicillium roqueforti
}

\author{
A.M. Rabie * \\ Food Science Department, Faculty of Agriculture, Zagazig University, Zagazig, Egypt
}

(received 25 November 1988, accepted 8 March 1989)

Summary - An attempt has been made to accelerate flavour development of blue cheese. Ripened cheese slurry has been incorporated into blue cheese curd at a rate of 1 and $2 \%$ respectively. A mixture of proteinases and lipases $(1: 1)$ of $P$. roqueforti has been incorporated into blue cheese curd at the proportions of 0.01 and 0.02 respectively. Blue cheese has also been made without additives (control).

Addition of either cheese slurry or enzyme mixtures to blue cheese curd has accelerated the development of the characteristic flavour of blue cheese. These additives have stimulated the formation of soluble nitrogenous compounds, free amino acids, volatile fatty acids and total carbonyl compounds.

Blue cheeses containing $2 \%$ ripened slurry or $0.02 \% P$. roqueforti enzymes have higher organoleptic properties than the control after $45 \mathrm{~d}$ of ripening. The concentrations of the previously mentioned compounds in the same period of ripening are higher than those found in control cheese after $60 \mathrm{~d}$.

$$
\begin{aligned}
& \text { ripening - blue cheese - protease - lipase - Penicillium roqueforti - proteolysis - } \\
& \text { lipolysis - flavour }
\end{aligned}
$$

Résumé - Accélération de l'affinage du fromage bleu par du "caillé hydraté" homogénéisé et par des enzymes extracellulaires de Penicillium roqueforti. Un essai a été fait pour accélérer le développement de la flaveur du fromage bleu. Du "caillé hydraté" homogénéisé a été incorporé dans du caillé de fromage bleu à raison de 1 à $2 \%$.

Un mélange de protéases et de lipases (1:1) de P. roqueforti a été également incorporé dans du caillé de fromage bleu à raison de 0.01 et $0.02 \%$. Le fromage bleu a été aussi fabriqué sans additifs (témoin).

L'addition soit du «caillé fluide» homogénéisé, soit du mélange d'enzymes, a accéléré le développement des flaveurs caractéristiques.

Ces addifits ont stimulé la formation de composés azotés solubles, d'acides aminés libres, d'acides gras volatils et des composés carbonylés totaux au cours de l'affinage.

Les fromages bleus contenant soit $2 \%$ de «caillé fluide" homogénéisé soit 0,02\% d'enzymes de P. roqueforti possèdent de meilleures propriétés organoleptiques que le témoin après 45 jours de maturation. Les concentrations des composés antérieurement mentionnés sont plus importantes dans la même période d'affinage que celles trouvées dans le témoin après 60 jours.

$$
\begin{aligned}
& \text { affinage - fromage bleu - protéase - lipase - Penicillium roqueforti - protéolyse - } \\
& \text { lipolyse - arôme }
\end{aligned}
$$

\footnotetext{
* Present address : Institut Supérieur d'Agriculture, BP 35, Gitega, Burundi.
} 


\section{INTRODUCTION}

Cheese ripening is a complex process which involves several biochemical reactions leading to the fermentation of lactose, breakdown of casein and hydrolysis of milk fat (Law, 1984).

Blue cheese undergoes extensive proteolysis during ripening (Kinsella and Hwang, 1976a; Hewedi and Fox, 1984) and the free fatty acids and methyl ketones produced are major contributors to the characteristic flavour of blue cheese (Lawrence, 1966; Jolly and Kosikowski, 1975; Kinsella and Hwang, 1976a,b; King and Clegg, 1979).

Several methods have been proposed to improve the quality of different types of cheese and shorten their ripening periods, such as increasing the ripening temperature, addition of modified starter (heat shocked), cheese slurry, trace elements or addition of enzymatic preparations (Hofi et al., 1973; Abdel Salam et al., 1981; Abdel Baky et al., 1982, 1986). Jolly and Kosikowski (1975) accelerated the development of blue cheese flavour by adding microbial lipases.

The incorporation into an aseptic curd of aspartyl protease of Penicillium roqueforti or metalloprotease of $P$. camemberti resulted in formation of high and low molecular weight peptides without liberation of amino acids. The liberation of amino acids resulted from the action of exopeptidases (Gripon et al., 1977).

Recently, the Polish National Committee of the IDF (1987) concluded that the most suitable method of accelerating cheese ripening is the use of enzymatic preparations obtained from the natural microflora of cheeses.

Therefore, the present investigation was carried out to accelerate blue cheese ripening, using either ripened blue cheese slurry or a mixture of crude proteolytic and lipolytic enzymes (1:1) secreted by P. roqueforti.

\section{MATERIALS AND METHODS}

\section{Materials}

Fresh cow's milk of $3.5 \%$ fat and $9 \%$ S.N.F. was used in this investigation. A rennet powder (1:100.000) was obtained from L.C. Glad Company A/S, Copenhagen, Denmark.

Pure cultures of $S$. lactis and $S$. diacetylactis were obtained from Hansen's Laboratory. The cultures were activated before being used. $P$. roqueforti strain R64A was kindly supplied by Dr Lenoir (INRA, Laboratoire de Recherche de la Chaire de Technologie, France).

\section{Preparation of cheese slurry}

The methods described by King and Clegg (1979) for preparing aseptic curd slurry were adopted.

Cow's milk of $3.5 \%$ fat and $9 \%$ S.N.F. was heated to $71-72^{\circ} \mathrm{C}$ for $15 \mathrm{~s}$, rapidly cooled to a setting temperature of $35^{\circ} \mathrm{C}$ and acidified to $\mathrm{pH}$ 5.6 with lactic acid. Rennet was then added to coagulate the milk ( $40 \mathrm{~min}$ ). The coagulum was cut and then it was ladled in cheese clothes for complete drainage over $24 \mathrm{~h}$. The resultant curd was firstly mixed with $4 \% \mathrm{NaCl}$, and transfered in to $500 \mathrm{ml}$ conical flasks. The curd was sterilized at $120^{\circ} \mathrm{C}$ for $15 \mathrm{~min}$. Sterilized curd was aseptically inoculated with $0.5 \%$ of Penicillium roqueforti mycelium and incubated at $25^{\circ} \mathrm{C}$ for 15 days.

\section{Production of crude enzyme preparations}

P. roqueforti strain R64A was cultured at $25^{\circ} \mathrm{C}$ for 5 days in Czapek-trypticase modified 
medium (Lenoir et al., 1979). The $\mathrm{pH}$ of the medium was adjusted to 4.0 for the production of aspartyl protease and acid carboxypeptidase, 6.5 for the production of metalloprotease, aminopeptidase and neutral carboxypeptidase, and 7.5 for the production of lipase (Lamberet and Lenoir, 1972).

The media were inoculated with $P$. roqueforti strain R64A. At the end of the incubation period, the vegetative growth was removed by centrifugation followed by filtering. The cell free extracts containing the enzymes were centrifuged at $2000 \mathrm{~g}$ for $20 \mathrm{~min}$. Equal volumes of extracts containing proteolytic enzymes were mixed and the enzymes were precipitated by acetone at a concentration of $80 \%$. The mixture was immediately centrifuged $(20 \mathrm{~min} \times 2000 \mathrm{~g})$ and the supernatant was discarded. The same procedure was followed with precipitation of lipolytic enzymes. The precipitate resulting from the extracts containing either proteolytic enzymes or lipolytic enzymes was weighed and dissolved in $0.025 \mathrm{M} \mathrm{Na}$-citrate buffer $\mathrm{pH} 4.0$. Insoluble material was removed by centrifugation (30 $\mathrm{min}$ $x 6000 \mathrm{~g}$ ). The mixture of crude proteolytic and lipolytic enzymes (1:1) was incorporated into the blue cheese curd at a level of 0.01 and $0.02 \%$.

\section{Cheesemaking}

Blue cheese was made from cow's milk containing $3.5 \%$ fat. Cow's milk was pasteurized at $71-72^{\circ} \mathrm{C}$ for $15 \mathrm{~s}$, and cooled to $30^{\circ} \mathrm{C}$. A starter culture consisting of Streptococcus lactis and Streptococcus diacetylactis (1:1) at a rate of $2 \%$ was added to cheese milk. Cheese making was completed as described by Kosikowski (1977). The resultant curd was inoculated with $P$. roqueforti and divided into 5 equal parts. The first part was left without additives and served as a control. Ripened cheese slurry was incorporated into cheese curd of the second and the third parts at a rate of 1 and $2 \%$ respectively. A mixture of crude proteolytic and lipolytic enzymes of $P$. roqueforti (1:1) was added at a rate of 0.01 and $0.02 \%$ of curd weight to the fourth part of the curd respectively. Cheese was ripened at $8-10^{\circ} \mathrm{C}$ and $95 \% \mathrm{RH}$ for 60 days.

\section{Organoleptic properties}

Cheese samples were organoleptically evaluated by the method of Spreer (1978) with maximum score points of $4.5,3.5$., 2.0 and 10.0 for external appearance, internal appearance, odour and taste respectively.

\section{Chemical analysis}

Cheese samples were analysed after salting, then after 30,45 and 60 days, for moisture, fat, salt, total nitrogen, soluble nitrogen and $\mathrm{pH}$ as described by Ling (1963). Amino acid nitrogen was determined according to the method of Stadhouders (1959).

\section{Total volatile fatty acids}

Free volatile fatty acids were determined by the method of Kosikowski (1977).

\section{Tyrosine and tryptophane}

Tyrosine and tryptophane were spectrophotometrically determined by the method described by Vakaleris and Price (1959).

\section{Total carbonyl compounds}

The total carbonyl concentration of blue cheese was determined by preparing 2,4-dinitrophenyl hydrazones of carbonyl compounds by the method of Lawrence (1965) and measuring the optical density at $340 \mathrm{~nm}$, using Safas Monaco Type 210 Spectrophotometer. Total carbonyl content was quantified using the molar extinction coefficient of 22,500 , since methyl ketones accounted for more than $90 \%$ of total carbonyls in solution.

\section{Statistical analysis}

The effects on scores of blue cheese of the addition of both ripened cheese slurry and 
Table I. Chemical composition of ripened blue cheese slurry.

\begin{tabular}{lr}
\hline Components & Values \\
\hline Moisture \% & 55.75 \\
Fat \% & 20.20 \\
Salt \% & 3.90 \\
Total N \% & 3.55 \\
Soluble N * & 35.80 \\
Tyrosine ** & 150.40 \\
Tryptophan ** & 120.70 \\
T.V.F.A. *** & 40.20 \\
pH & 5.80 \\
\hline
\end{tabular}

* Values are expressed as \% of total nitrogen. ** Values are expressed as $\mathrm{mg} / 100 \mathrm{~g}$ of cheese. ** T.V.F.A. : Total volatile fatty acids are expressed as $\mathrm{ml}$ of $0.01 \mathrm{~N} \mathrm{NaOH} / 100 \mathrm{~g}$ of cheese.

proteolytic and lipolytic enzymes to blue cheese curd were statistically analysed by the $F$ test. In cases of significant $F$, differences between treatments were examined by Duncan's multiple range test (Snedecor and Cochran, 1957).

\section{RESULTS AND DISCUSSION}

\section{Cheese slurry}

Table I shows the chemical composition of ripened blue cheese slurry. Ripened blue cheese slurry contained higher levels of soluble nitrogenous compounds, free amino acids and carbonyl compounds after 15 days of incubation. The flavour of typical blue cheese has developed during this period. Farag (1987) found that inoculation of aseptic blue cheese curd with different $P$. roqueforti strains showed a typical blue cheese flavour after 2 weeks of incubation at $25^{\circ} \mathrm{C}$.

\section{Gross chemical composition}

Table II shows that either addition of ripened cheese slurry or a mixture of proteolytic and lipolytic enzymes (1:1) to cheese curd had a slight effect on the moisture, fat and salt contents of blue cheese after salting and during ripening. Blue cheese containing either ripened slurry or enzymes mixture had different $\mathrm{pH}$ values compared with the control. The changes in the $\mathrm{pH}$ values between the control cheese and experimental cheeses were small after salting. As ripening proceeded, cheese containing either ripened slurry or enzymes mixture showed higher $\mathrm{pH}$ values than the control. On the other hand, cheese made with ripened slurry had slightly higher $\mathrm{pH}$ values than those made with enzyme mixtures after 45 days of cheese ripening. This may be due to the different rate of casein degradation at this stage of cheese ripening (Table III).

Generally, the $\mathrm{pH}$ values of both control cheese and all experimental cheeses gradually increased but at different rates during ripening. The observed difference between the control cheese and cheese containing slurry or enzyme mixtures may be due to the different rate of proteolysis occuring in blue cheeses containing the above mentioned additives (Table III). Similar results were obtained by Farag (1987).

The general trend of chemical composition of blue cheese containing ripened slurry agreed with that observed by Abdel Baky et al. (1982). They found that the utilization of cheese slurry to accelerate 
Table II. Gross chemical composition of blue cheese as affected by cheese slurry and enzymes mixture of $P$. roqueforti ${ }^{*}$.

Composition chimique globale du fromage bleu influencée par le caillé hydraté et des mélanges d'enzymes de P. roqueforti *.

\begin{tabular}{|c|c|c|c|c|c|c|}
\hline \multirow[t]{3}{*}{ Components } & \multirow{3}{*}{$\begin{array}{l}\text { Ripening } \\
\text { period } \\
\text { (days) }\end{array}$} & \multirow{3}{*}{$\begin{array}{l}\text { Without } \\
\text { additives } \\
\text { (control) }\end{array}$} & \multicolumn{4}{|c|}{ Additives } \\
\hline & & & \multicolumn{2}{|c|}{ Cheese slurry } & \multicolumn{2}{|c|}{ Enzyme mixtures } \\
\hline & & & $1 \%$ & $2 \%$ & $0.01 \%$ & $0.02 \%$ \\
\hline \multirow{4}{*}{ Moisture } & $\mathrm{F}$ & 48.7 & 48.8 & 48.4 & 48.8 & 48.8 \\
\hline & 30 & 45.6 & 45.7 & 45.8 & 45.6 & 44.6 \\
\hline & 45 & 44.5 & 44.6 & 44.7 & 44.4 & 44.6 \\
\hline & 60 & 44.3 & 44.4 & 44.4 & 44.2 & 44.4 \\
\hline \multirow{4}{*}{ Fat (DM) } & $F$ & 45.6 & 45.9 & 46.1 & 45.7 & 45.7 \\
\hline & 30 & 45.4 & 45.8 & 46.0 & 45.6 & 45.6 \\
\hline & 45 & 45.4 & 45.8 & 45.9 & 45.5 & 45.5 \\
\hline & 60 & 45.4 & 45.8 & 45.8 & 45.6 & 45.4 \\
\hline \multirow{4}{*}{ Salt } & $\mathrm{F}$ & 3.6 & 3.7 & 3.8 & 3.7 & 3.8 \\
\hline & 30 & 3.7 & 3.8 & 3.9 & 3.8 & 3.8 \\
\hline & 45 & 3.8 & 3.9 & 3.9 & 3.9 & 3.9 \\
\hline & 60 & 3.8 & - & 3.9 & 3.9 & 3.9 \\
\hline \multirow{4}{*}{$\mathrm{pH}$} & $\mathrm{F}$ & 4.8 & 4.9 & 4.9 & 4.9 & 4.9 \\
\hline & 30 & 5.2 & 5.4 & 5.6 & 5.3 & 5.5 \\
\hline & 45 & 5.8 & 6.2 & 6.4 & 5.9 & 6.14 \\
\hline & 60 & 6.2 & 6.7 & 6.8 & 6.5 & 6.7 \\
\hline
\end{tabular}

$\mathrm{F}=$ after salting. $\mathrm{DM}:$ dry matter. ${ }^{*}=$ average of 3 determinations.

ripening of Egyptian hard cheese (Ras) has a slight effect on the gross chemical composition of cheese.

\section{Ripening indices}

Changes in soluble nitrogen, amino acid nitrogen, soluble tyrosine and tryptophan contents, free volatile fatty acids and total carbonyl compounds were taken as indices of testing blue cheese ripening.

\section{Soluble nitrogen compounds and amino acids}

Table III indicates that the addition of ripened blue cheese slurry or enzymes mixture of $P$. roqueforti to blue cheese curd stimulated the formation of soluble nitrogenous compounds, tyrosine and tryptophan. However, the levels of these compounds were higher in cheese containing ripened blue cheese slurry 
Table III. Soluble nitrogen compounds and amino acids in blue cheese as affected by cheese slurry and enzymes mixture of $P$. roqueforti during ripening*.

Composés azotés solubles et acides aminés dans le fromage bleu influencés par le caillé hydraté et des mélanges d'enzymes de P. roqueforti au cours de l'affinage *.

\begin{tabular}{|c|c|c|c|c|c|c|}
\hline \multirow[t]{3}{*}{ Components } & \multirow{3}{*}{$\begin{array}{l}\text { Ripening } \\
\text { period } \\
\text { (days) }\end{array}$} & \multirow{3}{*}{$\begin{array}{l}\text { Without } \\
\text { additives } \\
\text { (control) }\end{array}$} & \multicolumn{4}{|c|}{ Additives } \\
\hline & & & \multicolumn{2}{|c|}{ Cheese slurry } & \multicolumn{2}{|c|}{ Enzyme mixtures } \\
\hline & & & $1 \%$ & $2 \%$ & $0.01 \%$ & $0.02 \%$ \\
\hline \multirow{4}{*}{ Soluble $N^{* *}$} & $\mathrm{~F}$ & 9.14 & 9.84 & 10.65 & 9.24 & 10.20 \\
\hline & 30 & 17.44 & 25.55 & 28.74 & 23.24 & 25.75 \\
\hline & 45 & 28.64 & 38.90 & 40.90 & 35.74 & 37.90 \\
\hline & 60 & 32.56 & 45.44 & 50.70 & 44.79 & 45.74 \\
\hline \multirow{4}{*}{ Amino $N^{* *}$} & $\mathrm{~F}$ & 1.44 & 1.66 & 1.84 & 1.72 & 1.84 \\
\hline & 30 & 5.60 & 7.40 & 7.94 & 6.94 & 7.50 \\
\hline & 45 & 7.40 & 9.64 & 10.49 & 8.55 & 9.40 \\
\hline & 60 & 9.77 & 11.84 & 12.50 & 11.26 & 12.25 \\
\hline \multirow{4}{*}{ Tyrosine *** } & $\mathrm{F}$ & 25.45 & 28.94 & 32.40 & 40.40 & 45.90 \\
\hline & 30 & 150.40 & 187.20 & 240.60 & 230.55 & 260.50 \\
\hline & 45 & 277.60 & 380.44 & 420.70 & 395.44 & 425.70 \\
\hline & 60 & 302.42 & 442.74 & 490.40 & 455.60 & 485.50 \\
\hline \multirow{4}{*}{ Tryptophan *** } & $\mathrm{F}$ & 15.45 & 20.44 & 24.45 & 26.70 & 30.40 \\
\hline & 30 & 95.65 & 115.55 & 140.60 & 125.88 & 155.50 \\
\hline & 45 & 185.40 & 210.62 & 270.40 & 220.70 & 235.35 \\
\hline & 60 & 210.74 & 250.44 & 295.36 & 240.44 & 279.40 \\
\hline
\end{tabular}

$\mathrm{F}=$ after salting. ${ }^{*}=$ average of 3 determinations. ${ }^{* *}=\%$ of total nitrogen. ${ }^{* * *}=\mathrm{mg} / 100 \mathrm{~g}$ of cheese.

than those containing enzyme mixtures or control blue cheese during ripening. The increased rate of both soluble nitrogenous compounds and amino acids was proportional to the amount of added cheese slurry and $P$. roqueforti enzyme mixtures. Addition of ripened blue cheese at a rate of $2 \%$ to the curd was more effective in this respect. Concentrations of soluble nitrogen, amino acid nitrogen and amino acids of blue cheese containing $2 \%$ of ripened slurry or $0.02 \%$ of $P$. roqueforti enzyme mixtures, at 45 days of cheese ripening, were higher than those of control at the end of the ripening period. The high rate of proteolysis in blue cheese containing ripened cheese slurry or mixture of proteolytic and lipolytic enzymes could be explained on the basis that cheese slurry contained $P$. roqueforti, which secretes a range of very active endo and exopeptidases which catalyse the degradation of casein (Zevaco et al., 1973; Lenoir et al., 1979).

On the other hand, cheese slurry contains a range of soluble, nitrogenous and amino acids compounds which probably stimulate the growth of $P$. roqueforti and enhance the formation of flavour compounds (Table I).

The results obtained agreed with those reported by Desmazeaud et al. (1976). 
Table IV. Free volatile fatty acids of blue cheese as affected by cheese slurry and enzymes mixture of $P$. roqueforti * during ripening.

Acides gras volatils du fromage bleu influencés par le caillé hydraté et des mélanges d'enzymes de P. roqueforti * au cours de l'affinage.

\begin{tabular}{|c|c|c|c|c|c|c|}
\hline \multirow[t]{3}{*}{ Components } & \multirow{3}{*}{$\begin{array}{l}\text { Ripening } \\
\text { period } \\
\text { (days) }\end{array}$} & \multirow{3}{*}{$\begin{array}{l}\text { Without } \\
\text { additives } \\
\text { (control) }\end{array}$} & \multicolumn{4}{|c|}{ Additives } \\
\hline & & & \multicolumn{2}{|c|}{ Cheese slurry } & \multicolumn{2}{|c|}{ Enzyme mixtures } \\
\hline & & & $1 \%$ & $2 \%$ & $0.01 \%$ & $0.02 \%$ \\
\hline \multirow{4}{*}{ T.V.F.A. ${ }^{* *}$} & $\mathrm{~F}$ & 2.4 & 3.2 & 4.1 & 3.8 & 4.5 \\
\hline & 30 & 18.4 & 35.6 & 50.8 & 30.4 & 42.4 \\
\hline & 45 & 36.2 & 55.7 & 74.4 & 60.4 & 65.2 \\
\hline & 60 & 56.8 & 71.4 & 86.7 & 79.2 & 92.8 \\
\hline \multirow{4}{*}{ T.C.C. ${ }^{* * *}$} & $\mathrm{~F}$ & 25.40 & 32.45 & 35.40 & 34.40 & 36.70 \\
\hline & 30 & 185.62 & 220.42 & 245.34 & 225.40 & 250.40 \\
\hline & 45 & 245.70 & 450.74 & 759.40 & 412.87 & 750.37 \\
\hline & 60 & 300.42 & 495.42 & 759.40 & 438.35 & 790.45 \\
\hline
\end{tabular}

* = average of 3 determinations. ${ }^{*}$ T.V.F.A. = total volatile fatty acids are expressed as ml of $0.01 \mathrm{~N} \mathrm{NaOH} / 100 \mathrm{~g}$ of cheese. ${ }^{* \star \star}$ T.C.C. $=$ total carbonyl compounds are expressed as $\mu \mathrm{mol} / 100 \mathrm{~g}$ of cheese.

They found that the proteolysis is very intensive in cheese curd inoculated with a strain of $P$. roqueforti. At the end of ripening, the soluble nitrogen at $\mathrm{pH} 4.6$, non-protein nitrogen and amino acid nitrogen, calculated as percent of total nitrogen, were 50,30 , and $10 \%$ respectively.

\section{Free fatty acids and carbonyl compounds}

Table IV shows the changes of free volatile fatty acids and carbonyl compounds in blue cheese containing ripened slurry or a mixture of proteolytic and lipolytic enzymes of $P$. roqueforti. Results showed that control blue cheese contained lower concentrations of free volatile fatty acids and carbonyl compounds than experimental cheeses made with either added cheese slurry or enzymes mixtures. Incorporation into cheese curd ripened slurry or enzyme mixtures accelerated the formation of free volatile fatty acids $\left(\mathrm{C}_{2}-\mathrm{C}_{10}\right)$ and total carbonyl compounds. These results could be explained on the basis that cheese slurry and enzyme mixtures contain acid lipases which are responsible for the liberation of short chain fatty acids from triglycerides of milk fat. Penicillium roqueforti can produce at least 2 lipases that are distinguished by their optimum $\mathrm{pH}$. Short-chain fatty acid specificities of these lipases influence the organoleptic qualities of blue veined cheese, because the amounts of each lipase vary widely from one cheese to another, being particularly related to the strain used and the ripening (Imamura and Kataoka, 1963). These volatile fatty acids are transformed in methyl ketones by either the spores or the mycelium of $P$. roqueforti (Dwivedi and Kinsella, 1974; Kinsella and Hwang, 1976b). Addition of ripened blue cheese slurry was more 
Table V. Organoleptic properties * of blue cheese as affected by cheese slurry and enzymes mixture of $P$. roqueforti.

Propriétés organoleptiques * du fromage bleu influencées par le caillé hydraté et les mélanges d'enzymes de P. roqueforti.

\begin{tabular}{|c|c|c|c|c|c|c|}
\hline \multirow[t]{3}{*}{ Characteristics } & \multirow{3}{*}{$\begin{array}{l}\text { Ripening } \\
\text { period } \\
\text { (days) }\end{array}$} & \multirow{3}{*}{$\begin{array}{ll}\text { Without } \\
\text { additives } \\
\text { (control) }\end{array}$} & \multicolumn{4}{|c|}{ Additives } \\
\hline & & & \multicolumn{2}{|c|}{ Cheese slurry } & \multicolumn{2}{|c|}{ Enzyme mixtures } \\
\hline & & & $1 \%$ & $2 \%$ & $0.01 \%$ & $0.02 \%$ \\
\hline External appearance (4.5) & & 4.0 & 4.0 & 4.0 & 4.0 & 4.0 \\
\hline Internal appearance (3.5) & & 2.8 & 2.9 & 3.1 & 2.7 & 3.0 \\
\hline Odour & 30 & 1.0 & 1.4 & 1.6 & 1.3 & 1.5 \\
\hline$(10.0)$ & & 6.4 & 7.2 & 8.5 & 7.2 & 7.4 \\
\hline$(20.0)$ & & $14.2 \pm 0.4$ & $15.5 \pm 0.2$ & $17.2 \pm 0.3$ & $15.2 \pm 0.1$ & $15.9 \pm 0.3$ \\
\hline External appearance (4.5) & & 3.9 & 3.9 & 3.8 & 3.8 & 3.8 \\
\hline Internal appearance (3.5) & & 2.9 & 3.1 & 3.2 & 3.0 & 3.0 \\
\hline Odour & 45 & 1.3 & 1.5 & 1.7 & 1.4 & 1.6 \\
\hline$(10.0)$ & & 7.6 & 8.1 & 8.3 & 8.1 & 8.2 \\
\hline$(20.0)$ & & $15.7 \pm 0.4$ & $16.6 \pm 0.2$ & $17.0 \pm 0.1$ & $16.3 \pm 0.4$ & $16.6 \pm 0.2$ \\
\hline External appearance (4.5) & & 3.8 & 3.8 & 3.8 & 3.7 & 3.7 \\
\hline Internal appearance (3.5) & & 3.0 & 3.1 & 3.2 & 3.1 & 3.2 \\
\hline Odour & 60 & 1.5 & 1.7 & 1.9 & 1.6 & 1.7 \\
\hline$(10.0)$ & & 8.0 & 8.1 & 8.2 & 8.2 & 8.0 \\
\hline$(20.0)$ & & $16.3 \pm 0.3$ & $16.7 \pm 0.2$ & $17.1 \pm 0.2$ & $16.6 \pm 0.2$ & $16.6 \pm 0.2$ \\
\hline Total general mean ** & & $15.4^{* *}$ & $16.3^{* *}$ & $17.1^{* \star}$ & $16.0^{* *}$ & $16.4^{* *}$ \\
\hline
\end{tabular}

" Mean \pm SEM of 3 determinations. " Values in the same row differ significantly $(P>0.05)$.

effective in this respect. The figures obtained were higher than those found by Godinho and Fox (1981) and agreed with those obtained by King and Clegg (1979) and Farag (1987).

\section{Organoleptic properties}

Table $\mathrm{V}$ shows the effect of the addition of either ripened cheese slurry or mixture of proteolytic and lipolytic enzymes (1:1) of $P$. roqueforti on the organoleptic properties of blue cheese during ripening. Organoleptic examinations showed that both cheeses containing ripened slurry or enzyme mixtures gave good organoleptic qualities of blue cheese compared with the control, but between the different treatments and the control cheese there were significant differences. However, best quality cheese was obtained when the cheese contained $2 \%$ blue cheese slurry. Descending order of quality were obtained with cheese made with $0.02 \%$ enzymes mixture, cheese containing $1 \%$ slurry and cheese made with added $0.01 \%$ enzymes mixture when compared with the control (Table V). Cheese containing $2 \%$ slurry was significantly superior to all treatments and acquired typical blue cheese flavour as well as 
good body characteristics earlier than control cheese. These results could be attributed to the high concentration of soluble nitrogenous compounds, free fatty acids and carbonyl compounds in blue cheese containing ripened slurry, since free volatile fatty acids and methyl ketones are major flavour of blue cheese (Jolly and Kosikowski, 1975; King and Clegg, 1979).

\section{CONCLUSION}

In this investigation an attempt was made to accelerate blue cheese ripening using ripened slurry and crude proteolytic and lipolytic enzymes secreted by $P$. roqueforti. These additives stimulated the reaction rate for the formation of important flavour compounds, such as free fatty acids, amino acids, and carbonyl compounds.

Addition of ripened blue cheese slurry or naturally produced proteolytic and lipolytic enzymes seems to be the most suitable method for accelerating cheese ripening. However, further studies concerning its application on an industrial scale should be investigated.

\section{ACKNOWLEDGMENTS}

The author is greatly indebted to Mr. E. Niyonzima, director of Dairy Development Centre of Kiryama, for his kind help during the manufacture of cheese.

\section{REFERENCES}

Abdel Baky A.A., El Fak A.M., Rabie A.M. \& El Neshawy A.A. (1982) Utilization of cheese slurry in the acceleration of cephalotyri (Ras) cheese ripening. Dairy Ind. 47, 21-25

Abdel Baky A.A., El Neshawy A.A. \& Ashor M.M. (1986) Heat shocked lactobacilli for accelerating development of Ras cheese. Food Chem. 21, 301-313

Abdel Salam M., El Shibiny S., Moneib A., Abou Heiba A. \& Al Khamy A.F. (1981) Addition of lipase in the manufacture of pickled soft cheese from whole milk and skim milk powder. Egypt. J. Dairy Sci. 9, 143-149

Anon (1987) Accelerated ripening of Tilsit and Edam cheese using enzymes prepared from the natural microflora of cheese. Bull. IDF 209, $51-52$

Desmazeaud M.J., Gripon J.C., Le Bars D. \& Bergère J.L. (1976) Etude du rôle des microorganismes et des enzymes au cours de la maturation des fromages. III. Influence des microorganismes. Lait 56, 379-396

Dwivedi B.K. \& Kinsella J.E. (1974) Carbonyl production from lipolyzed milk fat by the continuous mycelial culture of $P$. roqueforti. $J$. Food Sci. 39, 83-87

Farag A. (1987) Chemical and technological studies on blue cheese made from recombined milk. FhD Thesis, Zagazig University, Zagazig (Egypt)

Godinho M. \& Fox P.F. (1981) Ripening of blue cheese : influence of salting rate on lipolysis and carbonyl formation. Milchwissenschaft 36 , 476-478

Gripon J.C., Desmazeaud M.J., Le Bars D. \& Bergère J.L. (1977) Rôle of proteolytic enzymes of Streptococcus lactis, Penicillium roqueforti and Penicillium caseicolum during cheese ripening. J. Dairy Sci. 60, 1532-1538

Hewedi M.M. \& Fox P.F. (1984) Ripening of blue cheese : characterization of proteolysis. Milchwissenschaft 39, 198-201

Hofi A., Mahran G., Abdel Salam M. \& Riffaat I. (1973) Acceleration of cephalotyri (Ras) cheese ripening by using trace elements. II. Optimum conditions. Egyp. J. Dairy Sci. 1, 33-34 
Imamura T. \& Kataoka K. (1963) Biochemical studies on the manufacture of Roquefort type cheese. II. Characteristics of lipases produced by Penicillium roqueforti. Jpn. J. Zootech. Sci. 34, 344-348

Jolly R.G. \& Kosikowski F.V. (1975) Blue cheese flavour by microbial lipase and mould spores. J. Food Sci. 40, 285-297

King R.D. \& Clegg G.H. (1979) The metabolism of fatty acids, methyl ketones and secondary alcohols by Penicillium roqueforti in blue cheese slurries. J. Sci. Food Agric. 30, 197-202

Kinsella J.E. \& Hwang D.H. (1976a) Biosynthesis of flavours by Penicillium roqueforti. Biotechnol. Bioeng. 58, 927-938

Kinsella J.E. \& Hwang D.H. (1976b) Enzymes of Penicillium roqueforti involved in the biosynthesis of cheese flavour. CRC Crit. Rev. Food Sci. Nutr. 8, 191-228

Kosikowski F.V. (1977) Cheese and Fermented Milk Foods, Edward Bros Inc, Ann Arbor, Michigan

Lamberet G. \& Lenoir J. (1972) Aptitude de l'espèce Penicillium caseicolum à la production d'enzymes lipolytiques. Lait 52, 175-192

Lamberet G. \& Menassa A. (1982) Determination of lipolytic activity in blue veined cheese. Symposium International sur l'Utilisation des Enzymes en Technologie Alimentaire. Paris : Technique et Documentation Lavoisier.

Law B.A. (1984) Flavour development in cheese. In : Advances in the Microbiology and
Biochemistry of Cheese and Fermented Milk. (Davies F.L. \& Law B.A., eds), Elsevier Applied Science Publishers, London, 187-208

Lawrence R.C. (1965) Use of 2,4-dinitrophenyl hydrazin for estimation of microamounts of carbonyls. In : Carbonyl Production from Lipolyzed Milk Fat by the Continuous Mycelial Culture of P. roqueforti, Dwivedi B.K. \& Kinsella J.E. (1974) J. Food Sci. 39, 83-87

Lawrence R.C. (1966) The oxidation of fatty acids by spores of $P$. roqueforti. J. Gen. Microbiol. 44, 393-405

Lenoir J., Auberger B. \& Gripon J.C. (1979) Les caractères du système protéolytique de Penicillium caseicolum. III. Caractérisation d'une protéase acide. Lait 59, 244-268

Ling E.R. (1963) Dairy Chemistry, vol. 2 (3rd ed.) London, Chapman and Hall Ltd.

Snedecor G.W. \& Cochran W.G. (1957) Statistical Methods (5th ed.), lowa State Univ. Pren., Ames, lowa, USA

Spreer E. (1978) Technologie der Milchverarbeitung. VEB Verlag Leipzig

Stadhouders J. (1959) Hydrolysis of protein during the ripening of Dutch cheese. XV. International Dairy Congress, 2, 703

Vakaleris D.G. \& Price W.V. (1959) A rapid method for measuring cheese ripening. $J$. Dairy Sci. 42, 264-276

Zevaco C., Hermier J. \& Gripon J.C. (1973) Le système protéolytique de Penicillium roqueforti. II. Purification et propriétés de la protéase acide. Biochimie 55, 1353-1360 